\title{
A Road Less Travelled: Exploratory Practice-Driven Theory Development Opportunities in IS Project Management
}

\author{
Peter Reynolds \\ Australian Graduate School of Management, \\ University of New South Wales \\ email: peter.reynolds@agsm.edu.au \\ Philip Yetton \\ Australian Graduate School of Management, \\ University of New South Wales \\ email: phily@agsm.edu.au
}

\begin{abstract}
This paper reports on a high potential and under-utilised approach to developing theory to improve IS project performance, a significant and persistent problem for the IS discipline. It presents a multi-disciplinary approach to exploratory research, which is oriented towards solving problems in practice by developing new theory or adapting extant theory to a new milieu. This research approach is based on 'looking for a gap in practice and finding the theory in the gap'. It presents examples from a program of research that has provided a number of theories to improve IS project management performance. It shows that the IS field may require multiple theories to support the management of projects rather than a single theory of project management.
\end{abstract}

\section{Introduction}

This paper focuses on a high potential and under-utilised research approach to improve, through the development and application of new theory, IS project management performance. The development of theory to improve IS project management performance presents a major challenge to the IS discipline since IS project management has limited explicit theory (Shenhar, 1998; Williams, 2005) and delivers poor performance in practice with slow learning over time (Johnson et al., 2001; Standish Group, 2003, 2004).

This paper highlights the potential of 'exploratory practice-driven research', which builds on Kilduff's (2006) comments about the opportunities for deriving 
influential theories from the observation of real-life phenomena, and uses March's (1991) concepts of learning and knowledge creation.

Examples of solving problems in practice with new theory development are presented from an ongoing research program to improve IS project management. The research uses a multi-disciplinary research approach based on 'looking for a gap in practice' and 'finding the theory in the gap'. It shows that the IS field may require multiple theories to improve IS project management performance, rather than a single theory of IS project management.

The goal is to formalise a rigorous research approach, illustrated with examples, on which future research can build. We do not contend that exploratory practice-driven theory development is the only approach to improve IS project management performance. Rather, we highlight the research opportunities and describe an approach to improve performance.

The remainder of this paper is organised into four sections. First, we examine the available approaches to developing theory to improve IS project management, and describe the focus of this research. Next, we describe the research approach and theory development process. Following this, we present a number of examples and discuss the strengths and challenges of this approach when applied to IS project management. Finally, we present our conclusions.

\section{Theory development motivated by practice}

Nothing is so practical as a good theory (Lewin, 1945)

Theories make sense of the observable world and can provide significant breakthroughs in the way that problems are conceptualised and addressed (Chalmers, 1999). Good theory advances knowledge in a scientific discipline, guiding research towards critical questions. Good project theory would also be practical, improving the professionalism of management (Van de Ven, 1989). This section presents the case for exploratory practice-led theory development to improve IS project management performance. We begin by outlining the poor state of IS project management performance and the limited theory that currently underpins it. We then provide a typology of research approaches, noting the limited efforts to develop practice-driven theory. Finally, we discuss the benefits of this practice-driven approach with a specific focus on IS project management theory development.

\section{IS project management performance}

It must be considered that there is nothing more difficult to carry out nor more doubtful of success nor more dangerous to handle than to initiate a new order of things (Machiavelli, 1513) 
This research adopts the commonly accepted definition of a project as 'a temporary undertaking to create a unique product' (PMI, 2000). The undertaking is temporary because it has defined start and end dates, and it is unique because its purpose is to fulfil a specific requirement. Its performance is typically measured on four dimensions: time, cost, quality and functionality (Kerzner, 1998; Schwalbe, 2002; Turner, 1993).

Based on these definitions, IS project performance to date has been poor. Table 1 reports the findings from a series of longitudinal surveys conducted by the Standish Group since 1994. So-called 'challenged' projects are defined as being over budget, over schedule, or under specification. It should be noted, however, that these measures are against ex ante estimates of project time, cost, quality and functionality, which are affected by other dimensions including the socio - technical complexities involved with major projects and the human ability to produce accurate predictions (Kahneman et al., 1982). The research program on which we draw in this paper is broad, including studies into IT planning and IT investment processes and the way in which project managers effectively decompose, structure and sequence project and business outcomes.

\begin{tabular}{llll}
\hline Year & $\begin{array}{l}\text { Project Outcomes } \\
\text { Succeeded }\end{array}$ & Failed & Challenged \\
1994 & $16 \%$ & $31 \%$ & $53 \%$ \\
1996 & $27 \%$ & $40 \%$ & $33 \%$ \\
1998 & $26 \%$ & $28 \%$ & $46 \%$ \\
2000 & $28 \%$ & $23 \%$ & $49 \%$ \\
2003 & $34 \%$ & $15 \%$ & $51 \%$ \\
2004 & $29 \%$ & $18 \%$ & $53 \%$ \\
\hline
\end{tabular}

Table 1: IS project performance (Johnson et al., 2001; Standish Group, 2003, 2004)

The data in Table 1 show that there is a large disparity between achieved and projected performance, and that learning has been slow. This is consistent with other research on IS project success. For example, Field (1997) finds that about $40 \%$ of projects are cancelled before completion, and Ambler (1999) reports that some practitioners claim that, for large scale, mission-critical software projects, the failure rate has been as high as $85 \%$.

\section{IS project management theory}

Much of the accumulation of practical knowledge in IS project management has been driven by practitioners, who have amassed their collective knowledge of 'successful' practices into Bodies of Knowledge (BOK) such as the US-based Project Management Institute's (PMI) Project Management Body of Knowledge (PMBOK) (PMI, 2000). However, these bodies of knowledge lack a strong explicit theoretical base. In addition, there is often little formal evidence of the success of the espoused practices. 
In an analysis of the implicit theory underpinning these bodies of professional knowledge, Williams (2005) identifies three meta-theoretical assumptions that characterise the dominant discourse in current project management. Table 2 presents these assumptions.

Koskela and Howell (2002) review the theories that underpin project management as espoused in the PMBOK and that are frequently applied in practice. They show that the espoused practice rests on three theories of management: management as planning, the dispatch model of execution and the thermostat model of control. They conclude that these implicit and narrow theories are of limited value and explanatory power. They also note that they have already been superseded in the original management field from which they were imported.

In summary, practice dominates IS project management, with weak underpinning theory that could be developed, extended and enriched to improve project performance.

\begin{tabular}{|c|c|c|}
\hline Assumption & Description & Authors \\
\hline \multirow{2}{*}{$\begin{array}{l}\text { Project Management is rational } \\
\text { and normative }\end{array}$} & \multirow{2}{*}{$\begin{array}{l}\text { Project management presents itself as } \\
\text { self-evidently correct (and, therefore, } \\
\text { presumably an explicit espoused } \\
\text { strategy is not essential), providing a } \\
\text { normative set of techniques. }\end{array}$} & Lundin (1995) \\
\hline & & Packendorff (1996) \\
\hline $\begin{array}{l}\text { The ontological stance is } \\
\text { positivist }\end{array}$ & $\begin{array}{l}\text { Reality is 'out there' and the 'facts' of } \\
\text { a situation are observable. Further, the } \\
\text { observer is independent of the fact } \\
\text { under observation and can stand back } \\
\text { and observe the 'real' world } \\
\text { objectively. }\end{array}$ & Johnson and Duberley (2000) \\
\hline \multirow{4}{*}{$\begin{array}{l}\text { Project management is } \\
\text { particularly concerned with } \\
\text { managing scope }\end{array}$} & \multirow{3}{*}{$\begin{array}{l}\text { Project management decomposes the } \\
\text { total work effort into smaller chunks } \\
\text { of work with sequential dependencies } \\
\text { - giving rise to the standard } \\
\text { decomposition models; work } \\
\text { breakdown structures and project } \\
\text { networks, for example. }\end{array}$} & Remington and Crawford (2004) \\
\hline & & Soderlund (2001) \\
\hline & & Koskela and Howell (2002) \\
\hline & $\begin{array}{l}\text { Further, project management assumes } \\
\text { that tasks are independent (apart from } \\
\text { sequence and resource relationships), } \\
\text { tasks are discrete and bounded, } \\
\text { uncertainty as to requirements and } \\
\text { tasks is low, all work is captured by } \\
\text { top-down decomposition of the total } \\
\text { transformation, and requirements exist } \\
\text { at the outset and can be decomposed } \\
\text { along with the work. }\end{array}$ & \\
\hline
\end{tabular}

Table 2: Assumptions underpinning the dominant discourse in current project management (adapted from Williams, 2005).

\section{A focus on exploratory practice-driven research}

Kilduff (2006) argues that 'the route to good theory leads not through gaps in the literature but through an engagement with problems in the real-world that you find personally interesting'. He reiterates the observation of Hambrick (2005) 
that influential theories derive from the observation of real-life phenomena, not from 'scholars struggling to find holes in the literature'.

When motivated by a hole in the literature, researchers generally start with a problem within an existing theory, extend or refine it in some way, and apply it to a specific context (Kuhn, 1996). The nature of this learning and knowledge creation is 'exploitation' of the existing theory (March, 1991), including processes captured by terms such as refinement, choice, production, efficiency, selection, implementation and execution. Alternatively, researchers can address a gap in theory by starting with a new theory and testing it in a specific context. The nature of this learning and knowledge creation is 'exploration', including processes such as search, variation, risk taking, experimentation, play, flexibility, discovery, and innovation.

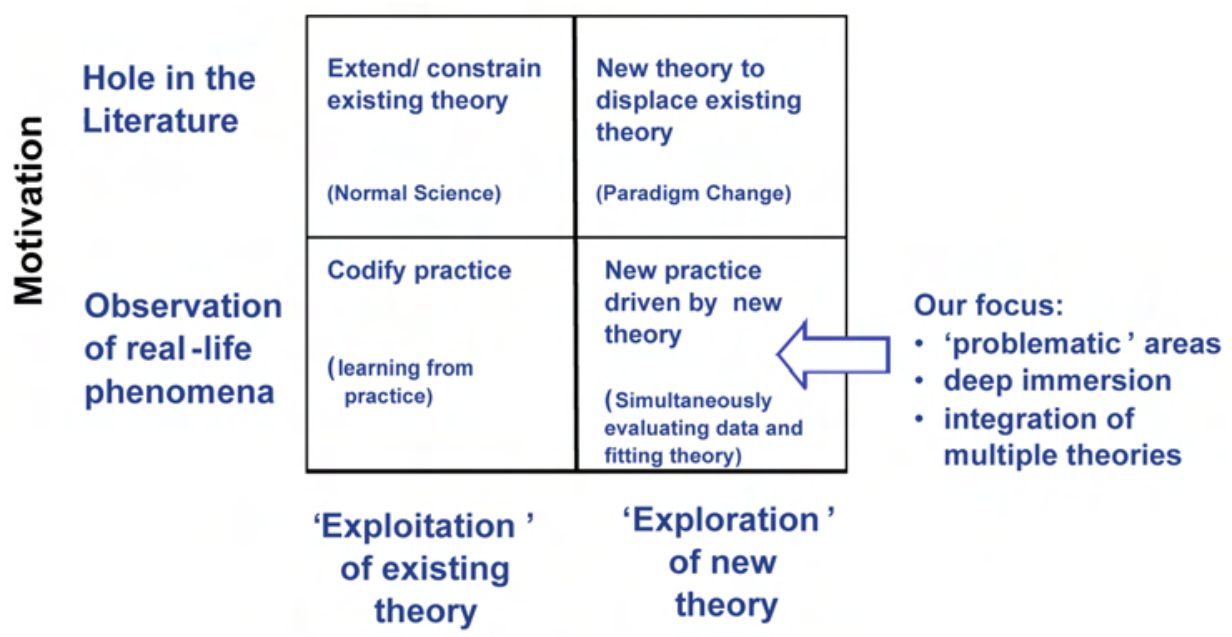

Learning/ Knowledge creation

\section{Figure 1: Theory development research typology.}

When motivated by the observation of practice, the problem is practice-driven, framed by the phenomena rather than by a well defined research model (Zmud, 1998). By not adopting a well-defined research model ex ante, this approach acknowledges that the research team does not know, a priori, the solution or the theory to be developed. Practice-led research that uses existing theories to codify best practice is exploitative. This includes research that seeks to improve project performance by developing more methodologies, better execution and stronger governance. Alternatively, and the focus of this paper, the research can be exploratory, looking to solve problems by drawing on new theories, frequently borrowed from other research domains. Integrating the two categories of theory development motivation (Kilduff, 2006) and learning and knowledge 
creation (March, 1991), Figure 1 presents a framework with exploratory practice-driven research located in the bottom right-hand quadrant.

Progress typically involves a mix of research approaches from all of the quadrants in Figure 1. Kuhn (1996) outlines the importance of the existing paradigm for conducting 'normal science', with punctuated changes to the status quo involving 'paradigm changes'. March (1991) contends that maintaining an appropriate balance between exploration and exploitation efforts is necessary for system survival and prosperity. This paper argues that the research in the bottom right hand quadrant holds great potential for unlocking the intransigent problems of IS project management performance, and that the current literature under-utilises it.

\section{A road less travelled}

Exploratory practice-driven research provides an environment for researchers and practitioners to collaborate, with the objective of solving a specific problem in practice and developing new theory, thus producing research that is both rigorous and relevant. In contrast to the usual debate around binary choices of rigor/relevance or theory/practice, this approach is simultaneously pursuing good science, which leads to new understanding, and practical solutions to critical problems. This is also known as Pasteur's quadrant (Mason, 2001).

In our view, exploratory practice-driven research is a high-potential approach to developing theory in the IS project management context where:

- Existing theory is inadequate or is of limited applicability;

- Trial and error learning has produced limited performance improvements;

- Identification of alternative theories is problematic;

- The source of the problem is unlikely to be close to its presenting symptoms; and

- Multiple theories are required to explain behaviour.

Practice-led research has an established acceptance and use within the IS discipline and various research designs are available to conduct this style of research, including case study and action research. Techniques to tackle the theory building process are rooted in the classic grounded theory paradigm from Glaser and Strauss (1967) and subsequent developments and debates - see Glaser (1992) and Strauss and Corbin (1997) . A notable application of grounded theory is Eisenhardt (1989), which provides an accessible framework for building theory based on case study research.

However, exploratory practice-driven research has not been extensively utilised in IS project management research. Nor are there clearly articulated steps to follow for theory development to derive theory from gaps in its practice. Instead, IS project management research has generally focused on holes in the existing 
literature, with researchers exploiting the limited existing theory to develop factor and process models (Markus and Robey, 1988; Robey and Newman, 1996; Sauer, 1999). As contexts appear where these do not hold, researchers introduce contingencies (Shenhar, 1998, 2001) and the various Bodies of Knowledge expand in detail and coverage. For example, as early as 1997, there were over 1,000 methodologies in use by the IS community (Fitzgerald, 1998).

Exploratory research intended to displace the existing dated theory has been limited, with a few notable exceptions such as the application of Adaptive Control Theory (Alleman, 2002) and a growing body of literature on the application, often using simulation techniques, of Complex Systems (Benbya and McKelvey, 2006; Morris, 2002; Williams, 2005). Exploratory practice-led research is all but absent in the IS project management literature.

\section{Research approach}

A model system or controller can only model or control something to the extent that it has sufficient internal variety to represent it. (Law of Requisite Variety or Ashby's Law ${ }^{1}$ )

Everything should be made as simple as possible, but not simpler. (Albert Einstein)

In support of the view that exploratory practice-driven research is high potential and under-utilised, this paper reports on a seven-year research program to improve IS project management. The researchers have conducted a series of engagements with practitioners to improve practice through the development of new theory. Each of the research studies draws on a different theoretical framework and generates different insights while building on the earlier engagements to improve project performance. The different frameworks provide the necessary variety, in Ashby's terms, to model and control improvements in project performance.

Examining the IS project management challenge early in the research program, the researchers concluded that there were at least three explanations for the failure to develop effective theories through which to manage large and complex IS project performance:

- Either the research community has failed to identify the right factors or processes, or factor and process models are insufficient by themselves;

- Project performance is subject to high contextual complexity and multiple contingencies; and

- Researchers have looked in the wrong places, wearing the wrong glasses.

1 The larger the variety of actions available to a control system, the larger the variety of perturbations it is able to compensate for. Ashby, R. 1958, 'Requisite variety and its implications for the control of complex systems', Cybernetica, vol.1, no. 2, pp. 1-17. 
- All three explanations suggest the challenge needs reframing, reinforcing the search for new theory.

\begin{tabular}{|c|c|c|c|}
\hline Objective & Step & Description & References \\
\hline \multirow[t]{2}{*}{ Engagement } & $\begin{array}{l}\text { Form a multi-disciplinary } \\
\text { team }\end{array}$ & $\begin{array}{l}\text { Access to multiple } \\
\text { frameworks }\end{array}$ & \multirow[t]{2}{*}{ Pettigrew (1990) } \\
\hline & $\begin{array}{l}\text { Immerse researchers in } \\
\text { practice }\end{array}$ & $\begin{array}{l}\text { Role in practice, direct } \\
\text { observation, participant } \\
\text { observation }\end{array}$ & \\
\hline \multirow[t]{4}{*}{$\begin{array}{l}\text { Looking for the gap } \\
\text { in practice }\end{array}$} & \multirow[t]{3}{*}{ Choose the 'gap in practice' } & $\begin{array}{l}\text { What is the unusual } \\
\text { behaviour? }\end{array}$ & \multirow[t]{3}{*}{ Benbasat and Zmud (1999) } \\
\hline & & A prepared mind & \\
\hline & & 'The problem of the problem' & \\
\hline & Articulate the problem & $\begin{array}{l}\text { What is done: } \\
\text { - What is problematic? } \\
\text { - Specific characteristics of } \\
\text { that world } \\
\text { - Limits of the domain }\end{array}$ & Klein and Myers (1999) \\
\hline \multirow[t]{8}{*}{$\begin{array}{l}\text { Finding the theory in } \\
\text { that gap }\end{array}$} & \multirow[t]{3}{*}{$\begin{array}{l}\text { Understand the ontological } \\
\text { and epistemological } \\
\text { underpinnings }\end{array}$} & $\begin{array}{l}\text { Consider the strengths and } \\
\text { limitations of the } \\
\text { meta-theoretical assumptions } \\
\text { that have either explicitly or } \\
\text { implicitly been adopted }\end{array}$ & \multirow[t]{3}{*}{ Weber (2003) } \\
\hline & & $\begin{array}{l}\text { What are the strengths and } \\
\text { limitations of their implicit } \\
\text { assumptions? }\end{array}$ & \\
\hline & & $\begin{array}{l}\text { What embedded assumptions } \\
\text { in the world might be relaxed } \\
\text { (testing assumptions)? }\end{array}$ & \\
\hline & \multirow[t]{3}{*}{$\begin{array}{l}\text { Form the evoked set of } \\
\text { theories }\end{array}$} & $\begin{array}{l}\text { Look at data in the gap to } \\
\text { signal which things will be } \\
\text { useful to point us towards } \\
\text { the theories }\end{array}$ & \multirow[t]{5}{*}{ Whetten (1989) } \\
\hline & & $\begin{array}{l}\text { Examine perspectives from } \\
\text { other fields }\end{array}$ & \\
\hline & & $\begin{array}{l}\text { - } \text { Propinquity } \\
\text { - } \text { Adjacencies } \\
\text { Deep and surface } \\
\text { structure }\end{array}$ & \\
\hline & \multirow{2}{*}{$\begin{array}{l}\text { Develop a combination } \\
\text { and/or permutation of } \\
\text { theories }\end{array}$} & $\begin{array}{l}\text { Which theories shed light on } \\
\text { the gap or are dispensable? }\end{array}$ & \\
\hline & & $\begin{array}{l}\text { Can multiple theories } \\
\text { integrate? }\end{array}$ & \\
\hline \multirow[t]{2}{*}{ Account } & \multirow[t]{2}{*}{$\begin{array}{l}\text { Develop an account of the } \\
\text { phenomena }\end{array}$} & $\begin{array}{l}\text { The explanation of the } \\
\text { hypothesised laws: }\end{array}$ & \multirow[t]{2}{*}{ Weber (2003) } \\
\hline & & $\begin{array}{l}\text { - } \text { Constructs } \\
\text { - Interactions } \\
\text { - States } \\
\text { - Lawful transitions }\end{array}$ & \\
\hline
\end{tabular}

\section{Table 3: Theory development approach.}

a The choice and articulation of the phenomena often occur concurrently rather than as discrete sequenced event. Weber, R. 2003, 'Editor's comments: Theoretically speaking', MIS Quarterly, vol. 27, no. 3, pp. iii-xii.

Table 3 presents the research approach. The approach is iterative within each step and adopts Burrell and Morgan's (1979) functionalist paradigm, which views 
social science as objective and ordered, reflecting the researchers' positivistic orientation.

\section{Engagement}

Practice-driven research involves a collaborative effort between a research team and the sponsors of the research effort (Zmud, 1998). This research program consists of a series of engagements with organisations, from both the public and private sectors, undertaking a program of IS-based business change. Engagements extended over a period of three to five years and involved deep immersion of the research team in the organisations followed by periods of reflection and theory development.

Engagements were conducted within various research frameworks, including single-case, multi-case, and longitudinal case studies (Yin, 2003); grounded theory (Eisenhardt, 1989; Strauss and Corbin, 1997) and action research (Baskerville and Pries-Heje, 1999; Susman et and Evered, 1978) .

The engagements provided theory-driven frameworks and recommendations. Researcher participation has ranged from direct observation in executive steering committees to participant observer (Jorgenson, 1989; McCall and Simons, 1969) undertaking project roles as well as being part of the research team. The extent of participant observation provided a unique perspective of operations across the organisations and extensive access to the research subjects. Understanding increases by being there as part of the project control system.

Formal data collection protocols applied to three primary forms of data. First, semi-structured interviews with individual informants were recorded, transcribed and validated. Second, direct observation augmented, compared and corroborated evidence in meetings, reviews and informal gatherings. Third, documents provided information on data gathered from interviews. These documents included strategic plans and business plans, proposals, reviews, policy and procedure manuals, release plans, project plans and specifications, reports, letters, minutes, memoranda and media clippings. Together, these multiple sources of data enabled triangulation of evidence (Carson et al., 2001).

The research background included organisational psychology, philosophy, political science, marketing, systems design and engineering. Some of the researchers have held senior positions in industry. This diverse set of theoretical and practical backgrounds enabled open dialogue and simultaneous engagement in robust debate with senior managers and between the researchers.

\section{Looking for the 'gap in practice'}

Weber (2003) describes the choice and articulation of the phenomena to be explained or predicted via theory as the two most critical tasks undertaken by researchers. 
When undertaking exploratory practice-driven research there are two characteristics that help to identify a gap in practice. The first is the absence of practice predicted by current theory. The second is observing practice that is inconsistent with current theory. Together, they strongly suggest that current theory is inappropriate as a basis from which to resolve the problem. Studying such events, which, for some reason, have behaved differently from what established knowledge would prescribe, is consistent with support for in-depth research in a single organisation (Sauer et al., 1997).

The identification of practice-driven research problems requires a prepared mind. Otherwise, the researcher simply treats departures from expectations as errors whereas the research team must be sensitive to such departures and assess them against their different theoretical backgrounds to identify unexpected insights. To do this, problem statements must be clearly articulated. Weick (1989) highlights that:

... the problem statements that drive the theorising process are more complex than they appear to be. Not only do they contain an anomaly to be explained, but they also contain a set of assumptions that can be confirmed or disconfirmed.

They require a description of what is problematic, the specific characteristics of and assumptions about the context, and identifications of limits to the domain.

A final challenge in practice-driven research is that the sponsors must also agree on the problem, with the sponsors often subject to stringent time requirements.

\section{Finding the 'theory in the gap'}

There is an extensive literature on what constitutes good theory but limited guidance on good theorising or how to develop good theory. Developing new theory to account for practice 'commonly involves borrowing a perspective from other fields, which encourages altering our metaphors and gestalts in ways that challenge the underlying rationales supporting accepted theories' (Whetten, 1989).

A useful place to start is to develop an understanding of the ontological and epistemological underpinnings and look at what researchers have taken for granted. It is then possible to challenge or relax the most accepted propositions in the current theory and to explore alternative explanations of the phenomena. To do the latter (that is, fit an alternative theory to the problem), researchers look for a theory, or theories, that simultaneously define the gap and account for the features in the gap. 


\section{Developing an account of the phenomenon}

Good guidelines are available for developing a theoretical account of a phenomenon. See, for example, Weber (2003) and Weick (1989). Weber (2003) describes this step as the explanation of the laws that are hypothesised, including their constructs, interactions, states and lawful transitions.

\section{Research progress and discussion}

So far, we have argued the case for exploratory practice-driven research and outlined the approach used in a program of research to improve project management. This section provides examples of the theory developed using this approach and discusses three key findings of the research. Specifically:

- the need for multiple theories;

- the value of multidisciplinary thinking; and

- the challenge of sustaining the focus on theory development.

\section{Examples of exploratory practice-driven research}

Table 4 describes four engagements, in which an observed gap in practice drove theory development. Two engagements describe situations characterised by an absence of practice predicted by current theory. The other two describe situations where the observed practice was inconsistent with current theory.

Bannerman (2004) provides a capability-based explanation of IS project management performance outcomes, as an alternative to the traditional factor and process view. It presents a theory of performance as the contested outcome of drivers for success (learning) and drivers for failure (liability of newness).

Vlasic and Yetton (2004) provide a time-based explanation of how the variance of tasks on a project generates a cumulative variance in project performance. Drawing on the Total Quality Management literature, they present a theoretical framework to explain poor performance driven by the relationship between task inter-dependence and task variance.

Thorogood and Yetton (2005) provide an explanation of how the currently dominant IT investment model, Net Present Value (NPV), drives the bundling of project delivery. The authors propose an alternative Real Options-based model to unbundle IT investment decisions, with the IT infrastructure investment as the premium paid by an organisation to execute a portfolio of business project options. The business units then assess each optional business project over time, resulting in decisions to execute, delay or discard.

Real Options provides the IT investment decision framework but not 'how' to unbundle projects. Reynolds (2006) addresses IS project complexity and uncertainty, and argues that modularity can unbundle projects to reduce the technical and organisational complexity of IS-based business transformations. 


\begin{tabular}{|c|c|c|c|c|}
\hline Engagement & $\begin{array}{l}\text { NSW Roads and } \\
\text { Traffic Authority }\end{array}$ & $\begin{array}{l}\text { South Australian } \\
\text { Water }\end{array}$ & $\begin{array}{l}\text { Commonwealth } \\
\text { Securities }\end{array}$ & Commonwealth Bank \\
\hline Case & $\begin{array}{l}\text { Further Down The } \\
\text { Open Road }\end{array}$ & $\begin{array}{l}\text { Raise Your Glasses } \\
- \text { The Water's } \\
\text { Magic! }\end{array}$ & $\begin{array}{l}\text { CommSec: } \\
\text { Australia's leading } \\
\text { on-line Stockbroker }\end{array}$ & $\begin{array}{l}\text { Building a New Bank: } \\
\text { Service Excellence } \\
\text { Everyday }\end{array}$ \\
\hline Timing & $1989-2001$ & $2002-2003$ & $1994-2001$ & $2003-2006$ \\
\hline Researcher role & $\begin{array}{l}\text { Post event } \\
\text { description, partial } \\
\text { direct observation }\end{array}$ & $\begin{array}{l}\text { Direct observation, } \\
\text { participant } \\
\text { observation }\end{array}$ & $\begin{array}{l}\text { Post event } \\
\text { description, partial } \\
\text { direct observation }\end{array}$ & $\begin{array}{l}\text { Direct observation, } \\
\text { participant } \\
\text { observation, action } \\
\text { research }\end{array}$ \\
\hline Level of analysis & Project, organisation & Project, department & Project, subsidiary & Project, organisation \\
\hline \multirow{2}{*}{$\begin{array}{l}\text { Gap in practice } \\
\text { Nature } \\
\text { Description }\end{array}$} & $\begin{array}{l}\text { Absence of practice } \\
\text { predicted by current } \\
\text { theory }\end{array}$ & $\begin{array}{l}\text { Absence of practice } \\
\text { predicted by current } \\
\text { theory }\end{array}$ & $\begin{array}{l}\text { Observed practice } \\
\text { inconsistent with } \\
\text { current theory }\end{array}$ & $\begin{array}{l}\text { Observed practice } \\
\text { inconsistent with } \\
\text { current theory }\end{array}$ \\
\hline & $\begin{array}{l}\text { Observed apparent } \\
\text { failure to develop } \\
\text { IS-based } \\
\text { competencies over } \\
\text { time (absence of } \\
\text { learning) }\end{array}$ & $\begin{array}{l}\text { Observed large } \\
\text { variance at } \\
\text { component level of } \\
\text { four projects despite } \\
\text { the same } \\
\text { organisational } \\
\text { context }\end{array}$ & $\begin{array}{l}\text { Observed investment } \\
\text { in technology } \\
\text { platform first and } \\
\text { then the } \\
\text { development of a } \\
\text { portfolio of business } \\
\text { applications to } \\
\text { respond to market } \\
\text { and technology } \\
\text { changes }\end{array}$ & $\begin{array}{l}\text { Observed unbundling } \\
\text { of a project to } \\
\text { reduce technical and } \\
\text { organisational } \\
\text { interdependencies } \\
\text { between project } \\
\text { components }\end{array}$ \\
\hline $\begin{array}{l}\text { Practices current } \\
\text { theory would predict }\end{array}$ & $\begin{array}{l}\text { Over time, learning } \\
\text { will improve } \\
\text { capabilities and the } \\
\text { ability to repeat a } \\
\text { similar task }\end{array}$ & $\begin{array}{l}\text { The application of a } \\
\text { standard } \\
\text { methodology in the } \\
\text { same context will } \\
\text { drive predictable } \\
\text { project performance }\end{array}$ & $\begin{array}{l}\text { New application and } \\
\text { business processes } \\
\text { justify infrastructure } \\
\text { changes }\end{array}$ & $\begin{array}{l}\text { Project is optimised } \\
\text { for time and cost (as } \\
\text { per PERT/ GERT/ } \\
\text { GANTT) }\end{array}$ \\
\hline $\begin{array}{l}\text { The theory in the } \\
\text { gap } \\
\text { Insight }\end{array}$ & $\begin{array}{l}\text { New technical and } \\
\text { organisational } \\
\text { conditions reset IS } \\
\text { learning and } \\
\text { capabilities }\end{array}$ & $\begin{array}{l}\text { Task } \\
\text { interdependence and } \\
\text { task variance drive } \\
\text { project performance }\end{array}$ & $\begin{array}{l}\text { Reframing of } \\
\text { projects using real } \\
\text { options to unbundle } \\
\text { IT infrastructure as } \\
\text { the option and a } \\
\text { portfolio of business } \\
\text { projects }\end{array}$ & $\begin{array}{l}\text { Traditional PM } \\
\text { techniques drive } \\
\text { technical and } \\
\text { organisational } \\
\text { inter-dependencies, } \\
\text { which increases } \\
\text { complexity and } \\
\text { reduces project } \\
\text { performance }\end{array}$ \\
\hline Theoretical base & $\begin{array}{l}\text { RBV, Liability of } \\
\text { Newness }\end{array}$ & $\begin{array}{l}\text { Total Quality } \\
\text { Management }\end{array}$ & Real Options & Complex Systems \\
\hline Constructs & Core capabilities & $\begin{array}{l}\text { Task } \\
\text { inter-dependence } \\
\text { Task Variance }\end{array}$ & $\begin{array}{l}\text { Investment models } \\
\text { and governance }\end{array}$ & $\begin{array}{l}\text { Uncertainty, } \\
\text { Complexity }\end{array}$ \\
\hline Account & Bannerman (2004) & $\begin{array}{l}\text { Vlasic and Yetton } \\
\text { (2004); Thorogood } \\
\text { et al. (2004) }\end{array}$ & $\begin{array}{l}\text { Thorogood and } \\
\text { Yetton (2004a, } \\
\text { 2004b, 2005) }\end{array}$ & $\begin{array}{l}\text { Reynolds et. al. } \\
\text { (2005); Reynolds } \\
(2006)\end{array}$ \\
\hline
\end{tabular}

Table 4: Application of exploratory practice-driven research.

\section{Multiple theories}

Table 4 presents multiple theories, each of which addresses a gap in practice with new theory, drawing from different reference disciplines. This range of theories has been used to provide insight into problems in IS project management performance and to develop new theory that can be applied to make sense of, predict or prescribe practice in IS project management.

If only a single theory were required to fill the IS project management gap, the contention is that it would be easy to develop. Academics and practitioners together would have rapidly applied the theory to solve the identified problem. 
Instead, this research shows that the IS field requires multiple theories to support the management of projects, rather than a single theory of project management.

\section{Multi-disciplinary thinking}

The ability to draw on multi-disciplinary thinking as described above has three major benefits. First, it enables easy access to alternative theoretical frameworks. Second, it provides access to a wide-range of research methods. Third, it supports deep immersion in the problem, generating strong engagement with practitioners.

The diverse theoretical backgrounds of the researchers supported the search for alternative theoretical frameworks and their initial evaluations. For example, from production engineering, the project critical path was treated as analogous to one run down a production line. The findings from Total Quality Management concerning variance-driven scheduling performance were then evaluated and integrated into the program. Similarly, Real Options Pricing was imported from investment theory to restructure the IS investment decision, with strong implications for both governance and the structure of the project and with both impacting directly on project performance. Looking in different places and through different lenses identified novel and powerful success factors.

A wide range of research methods can be applied. The selection of each is dependent on the research context and has included predominantly qualitative methods such as grounded theory, action research and interpretive case studies. It has also encouraged the research team, in other areas, to draw on quantitative methods such as structural equation modelling to allow simultaneous fitting of the data to the model and of the model to the problem.

Deep immersion in practice, with a multi-disciplinary team, supported a rich dialogue with practitioners. The managers involved in the projects evaluated all insights and this provided an early test against practice. Managers would know whether a proposal had already been tried and failed elsewhere in their industry. It also provided a guard against developing unnecessarily complex explanations, responding to Einstein's call to keep it simple, or as simple as possible. All this illustrates how, within this research approach, there is a natural tension between the need to develop richer theory while, at the same time, maintaining simplicity to explain and guide practice.

\section{Challenges}

Following the exploratory practice-driven approach described in this paper requires researchers to address three major challenges:

- avoid early closure;

- extend knowledge in practice; and

- ensure that the application of insights from other fields is used to develop new theory. 
The first major challenge requires that researchers remain both problem-focused and theory-focused, even when deeply immersed in practice. Without this discipline, it is easy to become solution-bound. The danger is that the practical problem is solved but the researchers do not generate new theory.

The second major challenge is to improve performance in practice and not just to reflect what is already known. The danger is that the researchers may explain only what is already known in practice. Lee (1999) states that 'with few exceptions, none of much significance, the scientists who turned to [practical needs] for their problems succeeded merely in validating and explaining, not improving, techniques developed earlier and without the aid of science'. This is almost certainly true for mature disciplines and practices. However, in immature areas with poor performance, such as IS project management, this is less of an issue. In addition, the approach of applying multi-disciplinary thinking allows new skills to be applied to practical problems.

The third major challenge is to ensure that the application of insights and models from other fields brings about new theory. To make a theoretical contribution, it is not sufficient to apply a theory from one field to a new context and to show that it works as expected. Whetten (1989) explains that the 'common element in advancing theory development by applying it in new settings is the need for a theoretical feedback loop. Theorists need to learn something about the theory itself as a result of working with it under different conditions. That is, new applications should improve the tool, not merely reaffirm its utility'.

The application of the approach in this paper addresses this by providing deep immersion to evaluate both data and theory. It allows the simultaneous fitting of data to the theory and fitting of the model to the data. In this way, theory is adjusted to reflect the empirical data and, at the same time, it is tested against that data.

Finally, the approach presented above is oriented around the developing of new theory using insights and existing theory from other fields. This, in itself, does not address calls for new theory in the 'core of IS'. Some, including Weber (2003), would argue that the IS discipline relies too much on theories borrowed or adapted from other disciplines. Instead the unique IS theory now becomes the integration of these theories, perhaps to the extent that others will want to borrow it.

\section{Conclusions}

Existing theory underpinning IS project management practice is weak, with much of the academic literature focusing on exploitation of the limited existing theory rather than exploration of new theory. In contrast, we argue in this paper that 'exploratory practice-driven research' is a high potential and under-utilised approach to address this challenge, where a multi-disciplinary team of researchers 
work with practitioners to solve significant problems while developing new theory. An approach is presented that focuses on 'looking for a gap in practice and finding the theory in the gap'. Four examples are presented.

A key finding of this paper is that there are likely to be multiple theories that support the management of IS projects as opposed to a single theory of IS project management. We have not attempted to identify and resolve the different gaps in practice and theory required to fill these gaps. Rather, we have presented a preliminary view based on our background and research program. While many theories can be borrowed from other fields and further developed, the unique challenge for the IS discipline becomes the need to provide an integration of these theories for its own purposes.

Finally, we have provided an approach that may prove fruitful for other areas of IS research where there is both a large and persistent gap in practice, and existing theory is weak and inadequate. In particular, this approach is powerful when there may be multiple problems, multiple theories required, it is not obvious where new theories may come from, and the problems are not close to their presenting symptoms.

\section{Acknowledgements}

The authors wish to acknowledge Dr Paul Bannerman, Dr Alan Thorogood, and Dr Anthony Vlasic for their critical role in this research and their feedback and perspectives provided during the development of this paper. In addition, the authors acknowledge the feedback and suggestions made by the two anonymous reviewers.

\section{References}

Alleman, G. B. 2002, 'A work in progress: Is there an underlying theory of software project management? (A critique of the transformational and normative views of project management)', Niwot, Colorado, p. 32.

Ambler, S. 1999, 'Comprehensive approach cuts project failures', Computing Canada, vol. 25, no. 1, pp. 15-6.

Ashby, R. 1958, 'Requisite variety and its implications for the control of complex systems', Cybernetica, vol. 1, no. 2, pp. 1-17.

Bannerman, P. 2004, 'The Liability of newness: Toward a capability-based theory of information systems performance', unpublished $\mathrm{PhD}$ thesis, The University of New South Wales, Australian Graduate School Of Management.

Baskerville, R. and Pries-Heje, J. 1999, 'Grounded action research: A method for understanding IT in practice', Accounting, Management and Information Technologies, vol. 9, pp. 1-23. 
Benbasat, I. and Zmud, R. W. 1999, 'Empirical research in information systems: The practice of relevance', MIS Quarterly, vol. 23, no. 1, pp. 3-16.

Benbya, H. and McKelvey, B. 2006, 'Toward a complexity theory of information systems development', Information Technology \& People, vol. 19, no. 1, pp. 12-35.

Burrell, G. and Morgan, G. 1979, Sociological Paradigms and Organisational Analysis: Elements of the Sociology of Corporate Life, Heinemann Educational Books Ltd, London, UK.

Carson, D., Gilmore, A., Perry, C. and Gronhaug, K. 2001, Qualitative Marketing Research Sage, London; Thousand Oaks, CA.

Chalmers, A. F. 1999, What is This Thing Called Science? An Assessment of the Nature and Status of Science and its Methods, 3rd ed., University of Queensland Press, St Lucia, Qld.

Eisenhardt, K. M. 1989, 'Building theories from case study research', The Academy of Management Review, vol. 14, no. 4), pp. 532-50.

Field, T. 1997, 'When bad things happen to good projects', CIO Magazine, pp. 55-62.

Fitzgerald, B. 1998, 'An empirical Investigation into the adoption of systems development methodologies', Information and Management, vol. 34, no. 6, pp. 317-28.

Glaser, B. and Strauss, A. 1967, The Discovery of Grounded Theory: Strategies for Qualitative Research, Aldine Publishing Company, Chicago.

Glaser, B. G. 1992, Emergence vs. Forcing: Basics of Grounded Theory Analysis, Sociology Press, Mill Valley, CA.

Hambrick, D. C. 2005, 'Upper echelons theory: Origins, twists and turns, and lessons learned', in Smith, K. G. and Hitt, M. A. (eds), Great Minds in Management : The Process of Theory Development, Oxford University Press, New York, pp. 109-27.

Johnson, J., Boucher, K.D., Connors, K. and Robinson, J. 2001, 'Project management: The criteria for success', Software Magazine, vol. 21, no. 1, pp. S3-S11.

Johnson, P. and Duberley, J. 2000, Understanding Management Research, Sage, London, UK.

Jorgenson, D. 1989, Participant observation: A Methodology for Human Studies, Sage, Newbury Park, CA.

Kahneman, D., Slovic, P. and Tversky, A. 1982, Judgment Under Uncertainty: Heuristics and Biases, Cambridge University Press. 
Kerzner, H. 1998, Project Management: A Systems Approach to Planning, Scheduling and Controlling, 6th ed., Van Nostrand Reinhold, New York.

Kilduff, M. 2006, 'Editor's comments: Publishing theory', The Academy of Management Review, vol. 31, no. 2, pp. 252-55.

Klein, H. K. and Myers, M. D. 1999, 'A Set of principles for conducting and evaluating interpretive field studies in information systems', MIS Quarterly, vol. 23, no. 1, pp. 67-93.

Koskela, L. and Howell, G. 2002, 'The underlying theory of project management is obsolete', Proceedings of the Project Management Institute Research Conference, Seattle, WA, pp. 293-301.

Kuhn, T. S. 1996, The Structure of Scientific Revolutions, (3rd ed.), University of Chicago Press, Chicago, IL.

Lee, A. S. 1999, 'Rigor and relevance in MIS research: Beyond the approach of positivism alone', MIS Quarterly, vol. 23, no. 1, pp. 29-33.

Lewin, K. 1945, 'The research center for group dynamics at Massachusetts Institute of Technology', Sociometry, vol. 8, no. 2), pp. 126-36.

Lundin, R. A. 1995, 'Editorial: Temporary organisations and project management', Scandinavian Journal of Management, vol. 11, pp 315-7.

Machiavelli, N. 1513, The Prince, <http://www.sidereus.org/library/theprince.htm $>$, Accessed 22 Aug 2007.

March, J. G. 1991, 'Exploration and exploitation in organisational learning', Organisational Science, vol. 2, no. 1, pp. 71-87.

Markus, L. M. and Robey, D. 1988, 'Information technology and organisational change: Causal structure in theory and research', Management Science, vol. 34, no. 5, pp. 583-98.

Mason, R. M. 2001, 'Not either/or: Research in Pasteur's quadrant', Communications of the AIS, vol. 6, no.16, pp. 1-6.

McCall, G. and Simons, J. 1969, Issues in Participant Observation, AddisonWesley, Reading, MA.

Morris, P. W. G. 2002, 'Science, objective knowledge and the theory of project management', Proceedings of the Institute of Civil Engineering Conference, pp. 82-90.

Packendorff, J. 1996, 'Inquiring into the temporary organisation: New directions for project management research', Scandinavian Journal of Management, vol. 11, pp 319-33.

Pettigrew, A. M. 1990, 'Longitudinal field research on change: Theory and practice', Organisation Science, vol. 1, no. 3, pp. 267-92. 
PMI, 2000, A Guide to the Project Management Body of Knowledge, Project Management Institute, Pennsylvania, USA.

Remington, K. and Crawford, L. 2004, 'Illusions of control: Philosophical foundations for project management', in: Proceedings of IRNOP Conference, Turku, Finland, pp. 563-77.

Reynolds, P. 2006, 'Managing requirements for a US\$1 bn IT-based business transformation: New approaches and challenges', Journal of Systems and Software (in press).

Reynolds, P., Thorogood, A. F. and Yetton, P. 2005, 'Reframing executive perception: a \$1 billion action research IT project', Winter International Symposium on Information and Communications Technology, ACM, Cape Town.

Robey, D. and Newman, M. 1996, 'Sequential patterns in information systems development: An application of a social process model', ACM Transactions on Information Systems, vol. 14, no. 1, pp. 30-63.

Sauer, C. 1999, 'Deciding the future for IS failure: Not the choice you might think', in Currie, W. L. and Galliers, R. (eds), Rethinking Management Information Systems: An Interdisciplinary Perspective, Oxford University Press, Oxford, UK.

Sauer, C., Yetton, P. W. and Associates 1997, Steps to the Future: Fresh Thinking on the Management of IT-Based Organisational Transformation, JosseyBass Publishers, San Francisco.

Schwalbe, K. 2002, Information Technology Project Management, Thomson Learning, Cambridge, MA.

Shenhar, A. J. 1998, 'From theory to practice: Toward a typology of projectmanagement styles', IEEE Transactions on Engineering Management, vol. 45, no. 1, pp. 33-48.

Shenhar, A. J. 2001, 'Contingency management in temporary, dynamic organisations: The comparative analysis of projects', Journal of High Technology Management Research, vol. 12, no. 2, pp. 239-71.

Soderlund, J. 2001, 'On the development of project management research: Schools of thought and critique', International Project Management Journal, vol. 8, pp. 20-31.

Standish Group 2003, 'Latest Standish Group CHAOS Report Shows Project Success Rates have Improved by 50\%', p. 1 .

Standish Group 2004, 'CHAOS Demographics and Project Resolution', p. 1.

Strauss, A. and Corbin, J. (eds) 1997, Grounded Theory in Practice, Sage Publications, London. 
Susman, G. I. and Evered, R. D. 1978, 'An assessment of the scientific merits of action research', Administrative Science Quarterly, vol. 23, no. 4, pp. 582603.

Thorogood, A. F. and Yetton, P. 2004a, 'Reducing complexity and market risk in major system upgrades: An extension of Real Options theory to information technology infrastructure', Proceedings of the 8th Pacific Asia Conference on Information Systems, Shanghai, PRC.

Thorogood, A. F. and Yetton, P. 2004b, 'Reducing the technical complexity and business risk of major systems projects', Proceedings of the 37th Hawaii International Conference on System Sciences, IEEE, Big Island, Hawaii.

Thorogood, A. F. and Yetton, P. 2005, 'Transforming the agility of IT infrastructure and projects through Real Options', Proceedings of the 5th European Academy of Management, Munich.

Thorogood, A. F., Yetton, P., Vlasic, A. and Spiller, J. 2004, 'Transforming a public sector utility: IT alignment, governance and outsourcing', Journal of Information Technology vol. 19, no. 2, pp. 130-9.

Turner, J. R. 1993, The Handbook of Project-Based Management, McGaw-Hill, London, UK.

Van de Ven, A. H. 1989, 'Nothing is quite so practical as a good theory', The Academy of Management Review, vol. 14, no. 4, pp. 486-89.

Vlasic, A. and Yetton, P. 2004, 'Why information systems projects are always late', Proceedings of the 15th Australasian Conference on Information Systems, Hobart, Australia.

Weber, R. 2003, 'Editor's comments: Theoretically Speaking', MIS Quarterly, vol. 27, no. 3, pp. iii-xii.

Weick, K. E. 1989, 'Theory construction as disciplined imagination', The Academy of Management Review, vol. 14, no. 4, pp. 516-31.

Whetten, D. A. 1989, 'What constitutes a theoretical contribution?', The Academy of Management Review, vol. 14, no. 4, pp. 490-95.

Williams, T. 2005, 'Assessing and moving on from the dominant project management discourse in the light of project overruns', IEEE Transactions on Engineering Management, vol. 52, no. 4, pp. 497-508.

Yin, R. K. 2003, Case Study Research: Design and Methods, (2nd ed.) Sage, Thousand Oaks, CA.

Zmud, R. W. 1998, 'Conducting and publishing practice-driven research', in Larsen, T.J., Levine, L. and DeGross, J. I. (eds), Information Systems: Current Issues and Future Changes, International Federation of Information Processing, pp. 21-33. 